\title{
Rethinking applied ELT: Life-responsive teaching in ESP classes and learners' satisfaction with life
}

Ketabi, Saeed

University of Isfahan, Isfahan, Iran (ketabi@fgn.ui.ac.ir)

Zabihi, Reza $\$

University of Isfahan, Isfahan, Iran (zabihi@hotmail.com)

Ghadiri, Momene

University of Isfahan, Isfahan, Iran (momene.ghadiri@gmail.com)

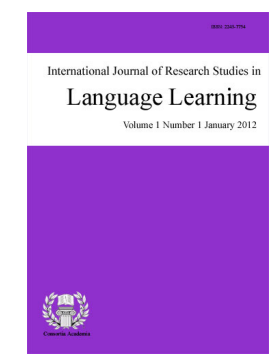

ISSN: 2243-7754 Online ISSN: 2243-7762

OPEN ACCESS

\section{Abstract}

Many philosophers of education as well as researchers have highlighted the importance of life skills training in education. Recently, the idea of life-wise instruction has been imported into the field of English language teaching after the introduction of notions such as applied ELT (Pishghadam, 2011) and life syllabus (Pishghadam \& Zabihi, 2012). This study was conducted to analyze L2 learners' level of life satisfaction and its relationship with their ESP teachers' life-responsive language teaching perceptions. For this purpose, two instruments, i.e. the Life-Responsive Language Teaching Beliefs Scale (LLTBS) and the Satisfaction with Life Scale (SWLS), were administered to Iranian ESP teachers $(N=164)$ and a sizeable sample of their learners $(N=800)$, respectively. For one thing, analysis of the questionnaire results displayed low levels of life-wise language teaching perceptions on the part of ESP teachers and low levels of satisfaction with life among learners. The results also demonstrated how language learners' scores on the satisfaction with life scale were significantly correlated with ESP teachers' life-responsive teaching beliefs. It was thus concluded that through the integration of life skills in ESP classes, materials developers, syllabus designers and ESP practitioners may become empowered to enhance learners' quality of life.

Keywords: life skills education; applied ELT; life syllabus; educational language teaching; life-wise language teaching; satisfaction with life; survey instruments 


\section{Rethinking applied ELT: Life-responsive teaching in ESP classes and learners' satisfaction with life}

\section{Introduction}

The significance of improving students' quality of life has been recognized by many educational philosophers (e.g., Dewey, 1897; Freire, 1998; Krishnamurti, 1981; Walters, 1997) and researchers in the context of education (e.g., Francis, 2007; Matthews, 2006; Noddings, 2003; Radja, Hoffmann, \& Bakhshi, 2008; Spence, 2003). Overall, life skills education may be looked at from several sources such as, inter alia, Humanistic education, World Health Organization (WHO), the Targeting Life Skills (TLS) Model, philosophy of Education for Life (EFL), the Human Development Paradigm (HDP), UNESCO Institute for Education, and Life Skills-Based Education (LSBE).

In this connection, much of the responsibility to teach life skills has been put on the shoulders of educational practitioners. In much the same way, the teacher professionalization has been reported by the Kothari Commission (1964-66) to be of high significance for improving the quality of education. Similarly, several researchers have unanimously pointed to the important role of teachers in students' success (e.g., Darling-Hammond, 2000; Day, et al., 2007; den Brok, Brekelmans, \& Wubbels, 2004; Rivkin, Hanushek, \& Kain, 2005). More specifically, a far as English education is concerned, several roles of language teachers can be drawn from the literature (Pishghadam, Zabihi, \& Kermanshahi, 2012).

For one, the pre-modern era of English language teaching was best characterized by the predominance of the Classical Method as the best approach to teach the language; in addition, the English teaching practitioner was considered as the sole authority in the class and typically used their own intuition for finding out the best way to teach the language. Further, the Classical Method, which was later known as the Grammar Translation Method, aimed at teaching classical languages like Latin and Greek through the translation of literary texts, focusing on rote learning of the lexicon and grammar rules. The proponents of this method ignored, to a great extent, listening and speaking skills, placing much more emphasis on vocabulary memorization, grammar rules, as well as reading and writing abilities.

With the entrance of ELT into the modern era, the English teaching practitioners were expected to behave exactly like native speakers of English. Moreover, monolingual teaching was regarded as best way of English teaching and teachers whose native language was English were considered to be the best teachers. These teachers were assigned the role of a technician and/or a classroom consumer. That is to say, as Kincheloe (1993) has pointed out, English teachers in the modern era transmitted the expert knowledge to language learners, disenfranchising the learners of their well-deserved right to change/modify the information content.

Next, the postmodern era of ELT emerged along with the notions of relativism, subjectivism, localism, and constructivism (Kuhn, 1962). In this way, several postmodern scholars such as, among others, Long (1989), Pennycook (1989), Kumaravadivelu (1994), Prabhu (1990), Stern (1991) and Richards (1990, 2003) denounced the modernist concepts and practices; conversely, these scholars tried to empower English teachers to reflect on their own teaching practices. Furthermore, English teaching practitioners were granted the right to criticize the dominant ideological, socio-political, and historical forces (Kumaravadivelu, 1999) in order to enable learners to obtain the necessary knowledge and skills to be able to act as critical agents in society (Auerbach, 1995; Pennycook, 1999).

Quite recently, with the advent of the Applied ELT theory (Pishghadam, 2011), which looked at the field of English language teaching as a super-ordinate and scientific field ready to contribute to and be applied to other domains of knowledge such as psychology and sociology, English teachers were recommended to move beyond 
reflective, critical, and participatory teaching of English towards adopting new roles as educational language teachers; in other words, these teachers should henceforth become interdisciplinary teachers who are not only experts in the ELT field, but also have a fair command of other disciplines as well (Pishghadam, Zabihi, \& Norouz Kermanshahi, 2012). That being said, English teachers are thus the key practitioners in improving a vast variety of life skills such as those proposed by the World Health Organization (WHO), i.e. critical thinking, creative thinking, problem solving, interpersonal relationship skills, decision making, coping with stress, coping with emotions, self-awareness, effective communication, and empathy and understanding.

This is in harmony with the assumptions of humanistic education which supports the idea that "education should empower people to lead a meaningful and purposeful life by boosting their intellectual and emotional abilities as well as their other types of relationships, attitudes, values and thinking styles" (Ketabi, Zabihi, \& Ghadiri, 2012, p. 2). According to Matheson and Grosvenor (1999), some core life skills should be improved in schools along with other academic subjects. Life skills are defined as "the abilities for adaptive and positive behavior that enable individuals to deal effectively with the demands and challenges of everyday life" (WHO, 1999). In this connection, many people (e.g., Brooks, 2001; Francis, 2007; Goody, 2001; Larson \& Cook, 1985; Matthews, 2006; Noddings, 2003; Radja, Hoffmann, \& Bakhshi, 2008; Spence, 2003; Walker, 1999) have placed premium on the fact that the above-mentioned life skills should be pre-scheduled to be enriched in educational contexts.

Nonetheless, it seems that in the case of English language teaching the ideas of life skills education are far from accepted or practiced. Put another way, both English language teachers and learners seem to be lagging behind in life skills training. Fortunately, the theory of Applied ELT, which points to the interdisciplinary and scientific nature of ELT, has now declared the independence of the field from linguistics and has assigned it a new role to contribute to other disciplines such as psychology, sociology and neurology. In addition, due to the fact that English language learning classes mostly enjoy several unique features they can smooth the way for the enrichment of many life skills, the idea of applied ELT was later on expanded by the introduction of life syllabus in the ELT curriculum (Pishghadam \& Zabihi, 2012). With that in mind, English language teaching professionals are henceforth reliable for enhancing learners' whole-person development, involving their intellectual development as well as other life skills which are essential to their lives.

\section{This Study}

As it was cited above, while there evidently seems to be an emergent need to enhance language learners' life qualities, the actual incorporation of life skills such as personal and social development, interpersonal relationships, effective communication, adaptive and positive behaviors, as well as feelings and emotions in the ELT curriculum still remains unclear. While the need to enhance the core life skills in language learners may appear self-evident, the potential integration of life syllabi in the ELT curriculum and the actual satisfaction with life that learners gain remain unanswered. Firstly, the present study seeks to analyze ESP teachers' beliefs as to the importance of including life skills in the English teaching curriculum. Secondly, it explores the extent to which language learners are satisfied with their lives. Thirdly, in this study it is tried to understand whether there is any significant relationship between ESP teachers' life-wise teaching perceptions and their learners' level of satisfaction with life. Therefore, this study addresses three research questions to be answered:

1. To what extent do ESP teachers hold life-wise language teaching beliefs?

2. To what extent are language learners satisfied with their lives?

3. Is there any significant relationship between ESP teachers' life-wise teaching perceptions and their learners' satisfaction with life? 


\section{Method}

\subsection{Participants}

\subsubsection{Teachers}

A total number of 164 Iranian EFL teachers at the University of Isfahan and Ferdowsi University of Mashhad, Iran, participated in this study. They ranged in age from 26 to 54 and were university lecturers holding majors in English teaching, linguistics, translation, or literature. The participants consisted of male $(\mathrm{N}=73)$ and female $(\mathrm{N}=91)$ EFL instructors. The detailed information on the teacher participants is displayed in Table 1.

\section{Table 1}

Distribution of participants (language teachers)

\begin{tabular}{|c|c|c|c|c|c|c|c|}
\hline Sex & & Age & & Degree & & Teaching Experien & \\
\hline Male & 73 & Twenties & 137 & English Teaching & 96 & Less than two years & 38 \\
\hline \multirow[t]{6}{*}{ Female } & 91 & Thirties & 19 & English Literature & 3 & 2-4 years & 54 \\
\hline & & Forties & 6 & English Translation & 20 & $5-9$ years & 48 \\
\hline & & Fifties & 2 & English Linguistics & 45 & $10-14$ years & 16 \\
\hline & & & & & & $15-19$ years & 5 \\
\hline & & & & & & 20-24 years & 2 \\
\hline & & & & & & $25-30$ years & 1 \\
\hline Total & 164 & & & & & & 164 \\
\hline
\end{tabular}

\subsubsection{Learners}

Of a total of learners being taught by the respective language teachers, 1052 undergraduate learners were randomly selected and were asked whether they would like to take part in the study. Among these, 800 learners agreed to complete a short scale. They ranged in age from 18 to 25 and were students of Physics, Biology, Genetics, Chemistry, Mathematics, Engineering, Psychology, and Persian Literature. The participants consisted of male $(\mathrm{N}=232)$ and female $(\mathrm{N}=568)$ ESP learners. The detailed information on the learner participants is displayed in Table 2.

Table 2

Distribution of participants (language learners)

\begin{tabular}{lllc}
\hline & Sex & \multicolumn{1}{c}{ Major } & 153 \\
Male & 232 & Physics & 126 \\
Female & 568 & Biology & 83 \\
& & Genetics & 76 \\
& & Chemistry & 68 \\
& & Mathematics & 144 \\
& & Engineering & 39 \\
& & Psychology & 111 \\
\hline Total & & Persian Literature & 800
\end{tabular}

\subsection{Data collection and analysis}

For the purpose of analyzing the level of ESP teachers' life-responsive language teaching, the Life-responsive Language Teaching Beliefs Scale was administered to 164 ESP teachers. The survey instrument is designed by Pishghadam, Zabihi, and Ghadiri (2012) to measure life-responsive language teaching beliefs, and validated via the implementation of Exploratory Factor Analysis (EFA), coming up with four subcomponents. 
These subscales include life-wise empowerment (15 items), adaptability enhancement (14 items), pro-social development (10 items), and life-over-language preference (6 items).

Apparently, it consists of 45 questions which are scored based on a 7-point Likert scale ranging from strongly disagree $(=1)$ to strongly agree $(=7)$. The Cronbach alpha reliability of the questionnaire has also been found to be .94 , displaying meritorious internal consistency. Similarly, the four underlying components of the scale enjoyed good reliability (i.e. from 0.90 to 0.57 ). Besides, while the internal consistency of the total number of questions in the present study was shown to be .87 , those of the subcomponents ranged from 0.53 to 0.83 . The results from descriptive statistics showed the level of ESP teachers' life-wise language teaching.

In order to examine the degree to which learners were satisfied with their lives, the Satisfaction with Life Scale (SWLS) was administered to learners. Developed by Diener, Emmons, Larsen and Griffin (1985), the SWLS encompassed a five-item questionnaire on a Liker scale of 7 points, ranging from strongly disagree $(=1)$ to strongly agree $(=7)$, which explored the language learners views on the extent to which their life was close to ideal, the conditions of their lives were excellent, they were satisfied with their lives, and they have achieved what they had wanted in life. The total score to be calculated out of the 5 items, ranged between 5 and 35 .

Moreover, the SWLS has consistently shown acceptable reliability estimates. For instance, while Abolghasemi and Varaniyab (2010) found an internal consistency of .82 for the scale, Koker (1991) reported an alpha reliability co-efficient of .80 . In the present study, an alpha reliability estimate of .85 was established. The SWLS scale also consisted of items inquiring about the background information of the participants regarding their age, gender and major. Since the two instruments were 7-point Likert scales, the Max and Min estimates were $7 \times 1$ respectively. Finally, the results of the descriptive statistics demonstrated the level of satisfaction with life on the part of language learners.

\section{Results and discussion}

\subsection{Research question 1}

For one, the researchers tried to find out the extent to which ESP teachers hold life-wise language teaching beliefs. The findings of the descriptive statistics pointed to the fact that ESP teachers in Iran tended to highlight, from among the four subscales of life-wise language teaching, the Pro-social Development and Life-Wise Empowerment of ESP learners. As it may be seen in Table 3, ESP teachers put emphasis on different factors of life-wise teaching from the most Pro-social Development (mean: 6.07) to the least Life-over-language Preference (mean: 4.89). In other words, they reckoned that the learners' personal and social development including interpersonal relationships and effective communication, their adaptive and positive behaviors, feelings and emotions as well as their mental well-being and behavioral alertness should be highlighted in ESP classes.

Table 3

The means of factors obtained from descriptive statistics

\begin{tabular}{lllc}
\hline & $\mathrm{N}$ & Mean & Alpha \\
\hline Pro-social Development & 164 & $\mathbf{5 . 0 7}$ & .689 \\
Life-wise Empowerment & 164 & 4.82 & .772 \\
Adaptability Enhancement & 164 & 4.12 & .836 \\
Life-over-language Preference & 164 & 3.89 & .535 \\
Valid N (listwise) & 164 & & \\
\hline
\end{tabular}


Ketabi, S., Zabihi, R., \& Ghadiri, M.

\subsection{Research question 2}

The second research question pertained to the extent to which language learners are satisfied with their lives. Table 4 presents the means for the five items in the questionnaire. The reliability of the scale estimated by Cronbach alpha was 0.85 . As it can be seen in the table, only one item generated the strongest conceptions with language learners expressing a firm agreement that they are satisfied with their lives $(M=5.01)$. However, other items received rather low scores, considering the fact that the highest possible score for each item has been equal to 7. For example, the other four items received scores from the most to the least as follows: If I could live my life over, I would change almost nothing $(\mathrm{M}=4.56)$; in most ways my life is close to my ideal $(\mathrm{M}=4.33)$; so far I have gotten the important things I want in life $(\mathrm{M}=4.02)$; and the conditions of my life are excellent $(\mathrm{M}=3.66)$. Therefore, taken together, it may be argued that the language learners felt they were not quite satisfied with their lives, that they felt they have not got all the important things they wanted in their lives, and that the conditions of their lives are far from being excellent.

Table 4

Mean scores of the questionnaire items

\begin{tabular}{lll}
\hline No. & Item & Mean \\
\hline 1 & I am satisfied with life. & $\mathbf{5 . 0 1}$ \\
2 & If I could live my life over, I would change almost nothing. & 4.56 \\
3 & In most ways my life is close to my ideal. & 4.33 \\
4 & So far I have gotten the important things I want in life. & 4.02 \\
5 & The conditions of my life are excellent. & 3.66 \\
\hline
\end{tabular}

\subsection{Research question 3}

The third research question asked whether there is any significant relationship between ESP teachers' life-wise teaching perceptions and their learners' satisfaction with life. Accordingly, a Pearson product-moment correlation coefficient was computed to assess the relationship between scores on the life-wise language teaching perceptions scale and those on the satisfaction with life scale. Most notably, as shown in Table 5, the results revealed that there is a significant correlation between life-responsive language teaching perceptions and learners' excellent life conditions $(r=0.322, \mathrm{p}<0.01)$, satisfaction with life $(\mathrm{r}=0.209, \mathrm{p}<0.05)$, and the closeness of their lives to their ideal $(\mathrm{r}=0.173, \mathrm{p}<0.05)$.

On the other hand, no significant correlation was found between life-responsive teaching conceptions of ESP teachers and learners' appraisal of the important things they have got in their lives $(r=0.101)$ as well as their intentions to change parts of their lives if they could live their lives over $(r=-0.090)$ (see Table 5).

\section{Table 5}

Correlations between life-responsive teaching and learners' life satisfaction

\begin{tabular}{ll}
\hline Items on SWLS & LLTBS \\
\hline In most ways my life is close to my ideal. & $0.173^{*}$ \\
The conditions of my life are excellent. & $0.322^{* *}$ \\
I am satisfied with life. & $0.209 *$ \\
So far I have gotten the important things I want in life. & 0.101 \\
If I could live my life over, I would change almost nothing. & -0.090 \\
\hline
\end{tabular}

Note. ${ }^{* *}$ Shows the existence of significant relationship at the level of 0.01

* Shows the existence of significant relationship at the level of 0.05 


\section{Conclusion}

Despite the fact that life satisfaction is an important notion throughout the world, it is worth noting that there is a paucity of research on the subject and particularly on the factors that help or hinder the enhancement of life satisfaction among students. The study reported in this article analyzed the beliefs of ESP teachers in Iran regarding the necessity of integrating life skills in the ELT curriculum in the form of life syllabi. In the light of the above results and discussion, some general conclusions may be drawn.

For one thing, analysis of the questionnaire results displayed low levels of life-wise language teaching perceptions on the part of ESP teachers. That is, in spite of the fact that the improvement of life skills has for longs been supported in educational contexts (Francis, 2007; Goody, 2001; Larson \& Cook, 1985; Radja, Hoffmann, \& Bakhshi, 2008; Spence, 2003), it seems that, as is evident from the results of the present research, ESP teachers in Iran are constantly falling behind in this regard. This study revealed that, except for the pro-social development of language learners, other subscales of life-responsive language teaching, i.e. life-wise empowerment, adaptability enhancement, and life-over-language preference were given low attention by ESP teachers.

Moreover, analysis of the data from a sizeable sample of ESP learners in Iran regarding their levels of life satisfaction demonstrated that, generally, these language learners tend to underestimate their satisfaction with life. In the light of this corollary, given the low levels of satisfaction with life among the learner participants, it is unfortunate that more illumination on how to implement life skills education has not appeared so far. Though at first sight the low levels of satisfaction with life among learners might seem somewhat daunting, there is enough evidence in the literature that, fortunately, life satisfaction is not a fixed trait among people and, provided that attempts are made to enhance life skills in the context of education, it can be modified.

As for the concerns of this study, the results demonstrated how language learners' scores on the satisfaction with life scale were significantly correlated with ESP teachers' life-wise teaching beliefs. It is thus concluded that through the integration of life skills in ESP classes, materials developers, syllabus designers and ESP practitioners may become empowered to enhance learners' quality of life and, thereby, increase their satisfaction with life. In this connection, there is enough hope that latest innovations in the field of English language teaching with their respective nomenclature such as applied ELT (Pishghadam, 2011), life syllabus (Pishghadam \& Zabihi, 2012), and educational language teaching (Pishghadam, Zabihi, \& Norouz Kermanshahi, 2012) might lead us to a point where several life skills are pre-scheduled to be improved alongside the relevant content areas.

\section{Pedagogical Implications}

Some pedagogical implications from the results of this study can be summarized as follows: First and foremost, the findings of this research can be a kind of consciousness-raising for the ESP teachers who should realize the importance of explicit teaching of life skills in ESP classes and pave the way for the incorporation of life syllabi in to the whole ELT curriculum (also see: Dabaghi, Zabihi, \& Rezazadeh, 2012; Ketabi, Zabihi, \& Ghadiri, in press). Moreover, ESP teachers should become acquainted with the variety of techniques and materials that may help improve the enrichment of learners' life issues. In addition, thanks to the interdisciplinary essence of English language teaching classes in general, and ESP classes in particular, it is recommended that there be a close interaction between English teachers and the professionals in other disciplines such as psychology, sociology, computer sciences, neurology, etc. to provide great opportunities for the enhancement of life skills among learners.

Other studies using large samples of ESP teachers in other countries as well as those involving other teachers within the domain of ELT may help us better delineate the nuances of difference in the attitudes of English teachers towards life-responsive teaching. It is also expedient to focus the future research attention on this aspect of research not only to enrich the present literature, but to gain an in-depth understanding of the level 
Ketabi, S., Zabihi, R., \& Ghadiri, M.

of satisfaction with life among different populations of language learners. A need is also felt that the professionals in the field of English language teaching realize the importance of explicit life skills instruction in ELT classes and the inclusion of life skills such as creativity, critical thinking, emotional intelligence, social intelligence, effective communication, etc. from the very beginning of the materials development process in the whole ELT curriculum. To achieve this purpose, it is required that language teachers refine their teaching perceptions so as to become more adaptive to life-responsive language teaching approaches and techniques, hence the need for studies to ascertain the ways through which the professionals in language teacher education programs can make teachers aware of such life-responsive philosophies whose outcome can definitely benefit the whole society.

\section{References}

Abolghasemi, A., \& Varaniyab, S. T. (2010). Resilience and perceived stress: Predictors of life satisfaction in the students of success and failure. Procedia Social and Behavioral Sciences, 5, 748-752. http://dx.doi.org/10.1016/j.sbspro.2010.07.178

Auerbach, E. R. (1995). The politics of the ESL classroom: Issues of power in pedagogical choices. In J. W. Tellefson (ed.). Power and inequality in language education. Cambridge: Cambridge University Press.

Brooks, R. (2001). Fostering motivation, hope, and resilience in children with learning disorders. Annals of Dyslexia, 51, 9-20. http://dx.doi.org/10.1007/s11881-001-0003-4

Dabaghi, A., Zabihi, R., \& Rezazadeh, M. (2012). Argumentative and narrative written task performance: Differential effects of critical thinking. International Journal of Research Studies in Language Learning, $1(2), 1-12$.

Darling-Hammond, L. (2000). Teacher quality and student achievement: A review of state policy evidence. Educational Policy Analysis Archives, 8(1). http://epaa.asu.edu/epaa/v8n1.

Day, C., Sammons, P., Stobart, G., Kington, A., \& Gu, Q. (2007). Teachers matter: Connecting lives, work and effectiveness. Maidenhead: OpenUniversity Press.

den Brock, P., Brekelmans, M., \& Wubbels, T. (2004). Interpersonal teacher behavior and student outcomes. School Effectiveness and School Improvement, 15, 407-442. http://dx.doi.org/10.1080/09243450512331383262

Dewey, J. (1897). My pedagogic creed. The School Journal, 54 (3), 77-80.

Diener, E., Emmons, R. A., Larsen, R. J., \& Griffin, S. (1985). The satisfaction with life scale. Journal of Personality Assessment, 49, 71-75. http://dx.doi.org/10.1207/s15327752jpa4901_13

Francis, M. (2007). Life skills education. Retrieved from http://www.changingminds.org

Freire, P. (1998). Pedagogy of freedom: Ethics, democracy, and civic courage. Lanham, Maryland: Rowman \& Littlefield Publishers, Inc.

Goody, J. (2001). Competencies and education: Contextual diversity. In: D. S. Rychen, \& L.H. Salganik (Eds.), Defining and selecting key competencies. Gottingen, Hogrefe and Huber Publications.

Ketabi, S., Zabihi, R., \& Ghadiri, M. (in press). Critical thinking across the ELT curriculum: A mixed methods approach to analyzing L2 teachers' attitudes towards critical thinking instruction. International Journal of Research Studies in Education.

Kincheloe, J. L. (1993). Toward a critical politics of teacher thinking. Westport: Bergin \& Garvey.

Koker, S. (1991). Normal ve Sorunlu Ergenlerin Yasam Doyumu uzeylerinin karsilastirilmasi [In

Turkish]. Unpublished Masteral thesis, Ankara/Turkey: Ankara University.

Krishnamurti, J. (1981). Education and the significance of life. HarperCollins Publishers.

Kuhn, T. (1962). The structure of scientific revolutions. Chicago: University of Chicago Press.

Kumaravadivelu, B. (1994). The post-method condition: Emerging strategies for second/foreign language teaching. TESOL Quarterly, 28, 27-48. http://dx.doi.org/10.2307/3587197

Kumaravadivelu, B. (1999). Theorizing practice, practicing theory: Critical classroom observation. In H. Trappes-Lomax and I. McGrath (Eds.). Theory in language teacher education (pp. 33-45). London: Prentice-Hall. 
Rethinking applied ELT: Life-responsive teaching in ESP classes and learners' satisfaction with life

Larson, D. G., \& Cook, R. E. (1985). Life-skills training in education. Journal of Group Psychotherapy, Psychodrama, \& Sociometry, 38(1), 11-22.

Long, M. H. (1989). Process and product in ESL program evaluation. Paper presented at the $5^{\text {th }}$ Annual TESOL Summer Meeting, Toronto, Canada, July, 21-32.

Matheson, D., \& Grosvenor, I. (Eds.) (1999). An Introduction to the study of education. London: David Fulton Publisher.

Matthews, B. (2006). Engaging education: Developing emotional literacy, equity, and co-education. McGraw-Hill Education: Open University Press.

Noddings, N. (2003). Happiness and education. Cambridge: Cambridge University Press. http://dx.doi.org/10.1017/CBO9780511499920

Pennycook, A. (1989). The concept of method, interested knowledge, and the politics of language teaching. TESOL Quarterly, 23 (4), 589-618. http://dx.doi.org/10.2307/3587534

Pennycook, A. (1999). Introduction: Critical approaches to TESOL. TESOL Quarterly 33, 329-348. http://dx.doi.org/10.2307/3587668

Pishghadam, R. (2011). Introducing Applied ELT as a new approach in second/foreign language studies. Iranian EFL Journal, 7 (2), 9-20.

Pishghadam, R., \& Zabihi, R. (2012). Life syllabus: A new research agenda in English language teaching. Perspectives, 19(1), 23-27.

Pishghadam, R., Zabihi, R., \& Ghadiri, M. (2012). Opening up a new pathway to the future of ELT: Design and validation of a life-responsive language teaching beliefs scale for L2 teachers. Proceedings of the $1^{\text {st }}$ Conference on Language Learning and Teaching: An Interdisciplinary Approach (LLT-IA), Ferdowsi University of Mashhad, Iran.

Pishghadam, R., Zabihi, R., \& Norouz Kermanshahi, P. (2012). Educational language teaching: A new movement beyond reflective/critical teaching. Life Science Journal, 9(1), 892-899.

Prabhu, N. S. (1990). There is no best method-why? TESOL Quarterly, 24, 161-176.

Radja, K., Hoffmann, A. M., \& Bakhshi, P. (2008). Education and capabilities approach: Life skills education as a bridge to human capabilities. Retrieved from http://ethique.perso.neuf.fr/Hoffmann_Radja_Bakhshi.pdf

Richards, J. C. (1990). The language teaching matrix. Cambridge: Cambridge University Press. http://dx.doi.org/10.1017/CBO9780511667152

Richards, J. C. (2003). Beyond methods. In Christopher Candlin and Neil Mercer (Eds.) English language teaching in its social context (pp. 167-179). London and New York: Routledge.

Rivkin, S. G., Hanushek, E. A., \& Kain, J. F. (2005). Variable definitions, data, and programs for teachers, students, and academic achievement. Econometrica Supplementary Material, 73(2). Retrieved from http://www.econometricsociety.org/ecta/supmat/4139data.pdf

Spence, S. H. (2003). Social skills training with children and young people: Theory, evidence and practice. Child and Adolescent Mental Health. 8(2), 84-96. http://dx.doi.org/10.1111/1475-3588.00051

Stern, H. H. (1991). Fundamental concepts of language teaching. Oxford: Oxford University Press.

Walker, J. C. (1999). Self-determination as an educational aim. In R. Marples (Ed.), The aims of education (pp. 112-123). London: Routledge.

Walters, J. D. (1997). Education for life: Preparing children to meet the challenges. Crystal Clarity Publishers.

WHO (1999). Partners in life skills education: Conclusions from a United Nations inter-agency meeting. Geneva: Department of Mental Health, Social Change and Mental Health Cluster, WHO. 


\section{Appendix A}

\section{The Life-responsive Language Teaching Beliefs Scale (LLTBS)}

\begin{tabular}{|c|c|}
\hline No. & Statement \\
\hline 1 & The primary goal of language classes should be language learning. \\
\hline 2 & Language teachers are responsible for enhancing learners' well-being. \\
\hline 3 & $\begin{array}{l}\text { The learners' ability to keep, make and end friendly relationships constructively should be practiced } \\
\text { and enhanced inside English classes. }\end{array}$ \\
\hline 4 & Language classes can become sites where learners' lives are enhanced. \\
\hline 5 & Language classes can teach learners how to empathize with others. \\
\hline 6 & Language teachers should have knowledge of other disciplines. \\
\hline 7 & Attending to learners' feelings and emotions deviates language teachers from teaching the language. \\
\hline 8 & Language classes have unique potentials for enhancing the quality of learners' lives. \\
\hline 9 & $\begin{array}{l}\text { An optimal goal of language learning tasks should be to enhance learner's decision-making } \\
\text { capabilities. }\end{array}$ \\
\hline 10 & An optimal goal of language learning tasks should be to enhance learner's problem-solving abilities. \\
\hline 11 & Language classes can teach children the essentials of mental health by giving training in life skills. \\
\hline 12 & Language classes should be sites to raise learners' self-awareness. \\
\hline 13 & Coping with stress and emotions should be practiced through language learning tasks. \\
\hline 14 & Language classes should be places where effective communication can be enhanced. \\
\hline 15 & Language classes should be places where interpersonal bonds can be strengthened. \\
\hline 16 & Language teachers should help learners build positive and healthy relationships. \\
\hline 17 & Language classes should be sites where learner's cultural identity is constructed. \\
\hline 18 & Life skills training in language classes may hinder the language learning process. \\
\hline 19 & $\begin{array}{l}\text { Learning how to relax, so that tensions created by unavoidable stress do not give rise to health } \\
\text { problems should be the purpose of a language class. }\end{array}$ \\
\hline 20 & $\begin{array}{l}\text { Audio-visual activities in my class mainly deal with enhancing effective communication or } \\
\text { interpersonal relationships. }\end{array}$ \\
\hline 21 & $\begin{array}{l}\text { Most feedbacks and discussions in my class revolve around linguistic points rather than enhancing the } \\
\text { quality of learners' lives. }\end{array}$ \\
\hline 22 & Language tasks should be designed in a way to enable learners to think diversely and extensively. \\
\hline 23 & $\begin{array}{l}\text { Language education should set out to facilitate the practice and reinforcement of learners' } \\
\text { psychosocial skills in a culturally and developmentally appropriate way. }\end{array}$ \\
\hline 24 & Language education can help the promotion of personal and social development. \\
\hline 25 & Language education can help the prevention of health and social problems. \\
\hline 26 & Language education can help the protection of human rights. \\
\hline
\end{tabular}


Rethinking applied ELT: Life-responsive teaching in ESP classes and learners' satisfaction with life

\begin{tabular}{|c|c|}
\hline 27 & $\begin{array}{l}\text { Language education can help other disciplines such as sociology, anthropology, psychology, } \\
\text { psychotherapy, etc. to enrich themselves. }\end{array}$ \\
\hline 28 & $\begin{array}{l}\text { Supporting mental well-being and behavioral preparedness should be the primary purpose of language } \\
\text { teaching. }\end{array}$ \\
\hline 29 & Language teaching should equip children to behave in pro-social ways. \\
\hline 30 & $\begin{array}{l}\text { Language teaching should be regarded as a means of empowering children and enabling them to take } \\
\text { more responsibility for their actions. }\end{array}$ \\
\hline 31 & $\begin{array}{l}\text { Language teachers should educate learners about life skills so that they can face with each trauma of } \\
\text { life with greater resilience and higher efficiency. }\end{array}$ \\
\hline 32 & Life skills education should only be the purpose of mental and behavioral disor \\
\hline 33 & $\begin{array}{l}\text { Effective application of language syllabi in English classes can influence the way children feel about } \\
\text { others and themselves. }\end{array}$ \\
\hline 34 & $\begin{array}{l}\text { Effective application of language syllabi in English classes can contribute to learners' self-confidence } \\
\text { and self-esteem. }\end{array}$ \\
\hline 35 & English language institutes should gain a high credibility with parents and community members. \\
\hline 36 & $\begin{array}{l}\text { A comprehensive language teacher-training program is needed to produce teachers who can enhance } \\
\text { learners' life qualities. }\end{array}$ \\
\hline 37 & $\begin{array}{l}\text { A comprehensive language teacher-training program is needed to produce teachers who can support } \\
\text { children's educational and mental health requirements. }\end{array}$ \\
\hline 38 & Language classes can act as a safety net by teaching students various life skills. \\
\hline 39 & $\begin{array}{l}\text { Fostering abilities for adoptive and positive behaviors that enable individuals to deal effectively with } \\
\text { the demands and challenges of everyday life should be practiced in English classes. }\end{array}$ \\
\hline 40 & Developing adaptive and forward-looking people should be the purpose of English education. \\
\hline 41 & $\begin{array}{l}\text { Active decision-making by assessing different options and what effects different decisions may have } \\
\text { should be the purpose of language learning tasks. }\end{array}$ \\
\hline 42 & $\begin{array}{l}\text { Language learning tasks should be designed in a way that increase the learners' ability to perceive } \\
\text { problems, seek and assess choices, make sound decision of each choice and solution and implement } \\
\text { suitable solution. }\end{array}$ \\
\hline 43 & $\begin{array}{l}\text { Divergent thinking, i.e. thinking in different dimensions for new inventions, should be practiced } \\
\text { through the proper design and application of language learning tasks. }\end{array}$ \\
\hline 44 & $\begin{array}{l}\text { The ability to recognize factors that influence attitudes and behavior such as values, peer pressure, and } \\
\text { the media should be practiced through language learning tasks. }\end{array}$ \\
\hline 45 & Language learners should become enabled to express their opinions and desires, needs and fears. \\
\hline
\end{tabular}




\section{Appendix B}

The Satisfaction with Life Scale (SWLS)

\begin{tabular}{|c|l|}
\hline No. & \multicolumn{1}{|c|}{ Statement } \\
\hline 1 & In most ways my life is close to my ideal. \\
\hline 2 & The conditions of my life are excellent. \\
\hline 3 & I am satisfied with life. \\
\hline 4 & So far I have gotten the important things I want in life. \\
\hline 5 & If I could live my life over, I would change almost nothing. \\
\hline
\end{tabular}

